\title{
Group Legal Services and the Constitution
}

\author{
Peter L. Zimroth $\uparrow$
}

\section{Group Legal Services and Legal Ethics}

The Chicago Motor Club, a non-profit organization of 60,000 automobile owners, provided various services for its members. It posted traffic signs, financed a schoolboy patrol, gave touring and motoring information, promoted legislation, and maintained emergency road services. It also provided legal services. If a member was arrested for a traffic violation, became involved in litigation concerning a traffic accident, or needed advice about the use or ownership of his car, he could consult a lawyer hired and paid by the Club out of Club dues. By pooling their financial resources, members provided lawyers for themselves in situations in which an individual member could not, either because he could not afford a lawyer or because the claim was too small. During one year (1931), the legal service handled 8,640 cases involving property damage caused by cars. The average amount per claim was $\$ 12.39 .^{1}$

The Chicago Bar Association claimed that the Club's service was unethical and sued to enjoin it. An Illinois commissioner found that the Club "rendered valuable services to its members and to the communities in which it operates,"2 and the Illinois Supreme Court characterized the Club's general activity as "beneficial." 3 But the Club was outlawed because it engaged in the "corporate practice" of law. "When the Chicago Motor Club offered legal services to its members . . . it was engaging in the business of hiring lawyers to practice law for its members." 4 The Club was also guilty of "commercialization."

Legal services cannot be capitalized for the profit of laymen, corporate or otherwise, directly or indirectly, in this State. . . . $[T]$ he public welfare demands that legal services should not be

$\dagger$ B.A. 1963, Columbia University; LL.B. 1966, Yale University.

The literature in this field has become vast, and I have tried to limit the footnotes. A bibliography of materials may be found at 12 U.C.L.A.L. REV. 456 (1965). Sec also the articles and notes in 41 Notre Dame Law. 843-905, 927-81 (1966), and authoritics cited therein.

1. People ex rel. Chicago Bar Ass'n v. Chicago Motor Club, 362 111. 50, 55, 199 N.E. 1, 3 (1935).

2. Id. at 52, 199 N.E. at 2.

3. Id. at 56,199 N.E. at 3 .

4. Id. at 56-57, 199 N.E. at 4 . 
commercialized, and that no corporation, association or partmership of laymen can contract with its members to supply them with legal services, as if that service were a commodity which could be advertised, bought, sold and delivered.5

The Brotherhood of Railroad Trainmen had a different idea about how to provide legal assistance for its members. Instead of hiring its own lawyers, it recommended a selected group of lawyers, screened for their competence and honesty, to all injured Brothers. ${ }^{\circ}$ Because the lawyers could expect a continuing stream of cases, they were willing to charge lower contingent rates and also to contribute part of their fees to the Legal Aid Bureau of the Brotherhood. The Legal Aid Bureau investigated all accidents, informed injured workmen about the program, tried to convince them to see the recommended lawyers, and generally advertised the legal service to the Brothers. Through this plan, the Brotherhood insured to its members relatively cheap ${ }^{7}$ and effective legal assistance.

The Brotherhood had an obvious interest in the plan. It had been the moving force behind the passage of the Federal Employers Liability Act and the Safety Appliance Act and did not want the benefits obtained for the members in Congress to be eroded in court. ${ }^{8}$ An Ohio court, scrutinizing the plan, "conceded that the object of the plan, so far as the Brotherhood is concerned is a noble one." But again, as in the Chicago Motor Club case, nobility of purpose could not save the plan, which the court said amounted to "solicitation." The finding that the Brotherhood solicited business for the recommended lawyers and the conclusion of illegality were treated as equivalent..$^{10}$

These two cases were decided during the 1930's. In that period group legal services were outlawed regularly. ${ }^{11}$ Today there is a new effort to establish these programs. Since the federal government has made the fight for legal representation a battle in the War on Poverty, the Office

5. Id. at 57, 199 N.E. at 4 .

6. In re Petition of the Comm. on Rule 28 of the Cleveland Bar Ass'n, 15 Ohio L. Abs. 106 (Ohio App. 1933).

7. Twenty per cent contingent fee in 1933, twenty-five per cent in 1964. See Bodle, Group Legal Services: The Case for BRT, 12 U.C.L.A. I. REv. 306, 311-12 (1965).

8. Id. at 306-10; Brotherhood of Railroad Trainmen v. Virginia ex rel. Va. State Bar, 377 U.S. 1, 3-4 (1964).

9. In re Petition of the Comm. on Rule 28 of the Cleveland Bar Ass'n, 15 Ohio $\mathrm{L}$. Abs. 106, 107 (Ohio App. 1933).

10. Id. at 108 .

11. E.g., Richmond Ass'n of Credit Men v. Bar Ass'n of City of Richmond, 107 Va. 327, 189 S.E. 153 (1937); In re Opinion of the Justices, 289 Mass. 607, 194 N.E. 313 (1935); Pcople ex rel. Courtney v. Association of Real Estate Taxpayers, 354 IIl. 102, 187 N.E. 823 (1933). 
of Economic Opportunity has funded 170 neighborhood law programs which will finance groups of lawyers so that they can represent the poor without charge. Approximately 140 of these programs are already operational. Labor unions, civil rights and civil liberties organizations, trade associations, and the United States Army ${ }^{12}$ have similar plans.

Large segments of the bar now support these efforts, but some do not. And these are fighting hard, with the rules of legal ethics as their weapons. The legality of OEO's program has been challenged in at least five cities. The program has been upheld in Philadelphia, ${ }^{13}$ Houston $^{14}$ and Modesto, California. ${ }^{15}$ Litigation is still pending in Orlando, Florida. ${ }^{16}$ But in New York the program was denied a charter (with leave to file a new application) at least in part because the proposed program violated some of the rules of legal ethics.17

This, then, is the problem: a group of people organize to provide cheaper or more efficient legal service for themselves or for others; no one challenges the utility of the organization, only its legality; the challenge may be successful because the organization has committed or will commit an ethical sin. And the number of sins is immense: maintenance, champerty, barratry, solicitation, inciting litigation, advertising, channeling, commercialization, corporate practice, unauthorized practice, ambulance chasing, lay intermediary, control of litigation.

The idea that the old rules of legal ethics should affect contemporary legal practice at all seems strange. So many of them emerged when the legal profession was a small, elite, compact community. Lawyers trained, lived, socialized, and worked together in a friendly and noncompetitive atmosphere. Many of the so-called rules of legal ethics were really rules of etiquette designed more to keep the group congenial than to benefit the public. ${ }^{18}$ The mid-twentieth century legal profession resembles its ancestor only in romantic fancy. Today's lawyer trains in one of the many law schools throughout the country. His sense of com-

12. See Winkler, Legal Assistance for the Armed Forces, 50 A.B.A.J. 450 (1964),

13. In re Community Legal Services, Inc., Pa. C.P. 4, March Term, 1966, No. 4968 (35 U.S.L.W. 2017, June 30, 1966).

14. Touchy v. Houston Legal Foundation, No. 722538 (D. Ct. Harris County, Texas, 165th Jud. Dist., March 7, 1967).

15. Stanislaus County Bar Ass'n v. California Rural Legal Assistance, Inc., No. 98302 (Dept. No. 4 Stanislaus County, California, October 12, 1966).

16. Troutman v. Shriver, Civil Action No. 66-188 (M.D. Fla.). The Florida Bar Associle. tion's Committee on Professional Ethics has issued an advisory opinion upholding the proposed Tampa program. Advisory Opinion No. 66.56 (March 10, 1967). The opinion, of course, is not binding on any court, though it may have a great influence.

17. In re Community Action For Legal Services, Inc., 26 App. Div. 2d 354, 274 N.X.S.2d 779 (1966). On the OEO and similar programs, see Note, Neighborhood Law Offices: 'The New Wave in Legal Services for the Poor, 80 Harv. L. REv. 805 (1967).

18. H. DRINKER, LEGAL ETHics 210-12 (1953). 
munity with most of his fellow students must be slight. He enters a highly competitive profession which, at least in many of its outward manifestations, cannot be distinguished from other American businesses. But it is too simple to reject the rules of legal ethics by saying that times have changed. If we are not willing to accept rules solely because they have existed, neither should we reject them solely because they are old. Some rules of legal ethics are based on wise policies which have relevance today. Yet even these rules are so broadly and so indiscriminately applied that they seem to outlaw as many beneficial practices as they do harmful ones. Our task is to understand these policies and then to fashion rules which fit the policies precisely.

\section{Maintenance, Champerty, and Barratry}

Rules prohibiting maintenance (helping another prosecute a suit), champerty (maintaining a suit in return for a financial interest in the outcome), and barratry (a continuing practice of maintenance or champerty) are among the most potent rules used to outlaw group legal services. Indeed, these rules strike at the heart of many group efforts because the groups have as their reason for existing the desire to help people prosecute claims which might not be prosecuted otherwise. The policies behind the three prohibitions are similar, and they are discussed together here.

The English common law followed the Greek and Roman law in prohibiting maintenance, champerty, and barratry. The two ancient civilizations prevented a disinterested third party from helping litigants maintain suits because the maintenance could be used to oppress poor people or to vex political opponents. The prohibitions were not universal, though. Generally, when one of the two parties was substantially weaker, intervention was permitted to protect him. When the maintainer did not have the required vexing or oppressing motive, he was not punished. Nor was he punished when his suit was successful, even if he had the forbidden motive. The evil to be prevented was the abuse of legal processes to oppress or annoy people who had done no wrong. If the other party in fact had done something wrong, or if the maintainer did not act maliciously, the process was not abused.19

To these reasons for prohibiting maintenance the English added three of their own. First, maintenance was particularly obnoxious to the King since it represented an attempt by the powerful feudal lords

19. Radin, Maintenance by Champerty, 24 CArIF. I. REv. 48, 48.57 (1935). 
to increase their influence by giving support to their retainers without regard to the validity of the claim..$^{20}$ Second, when a person maintained a suit in return for a financial interest in the outcome, the speculative nature of his interest was viewed as immoral.21 Finally, when someone maintained a suit, he stirred up litigation which might not have been brought otherwise. And understandably, litigation, which during the common law's infancy often consisted of trial by battle or ordeal, was not highly thought of. ${ }^{22}$

None of these three additional reasons has much validity today. The authority of the central government has been well enough established so that it need not worry about people who maintain suits to gain power and prestige. The attitude against speculation in general has changed, as has the attitude against speculation in litigation. The assignment of choses in action which fits the definition of champerty is now a common practice. ${ }^{23}$ Contingent fee contracts, another example of champerty, are also increasingly being accepted. ${ }^{24}$ The policy against litigation, at least in its original guise, ${ }^{25}$ cannot be justified either since trial by battle and ordeal is no longer a real threat.

There are, however, valid uses for the rules against maintenance, champerty and barratry. These rules can be used, as they were for the Greeks and the Romans, to prevent oppressive and vexatious litigation, to protect harassed litigants, and to protect the integrity of the legal process. In order to serve these functions, though, the rules must be refashioned in terms of the motive of the maintainer and the outcome of the litigation.

Although the development has not been constant, the trend in the law of maintenance seems to be towards focusing more sharply upon the real evils of vexation and oppression..$^{20}$ The comprehensive scope and application of the common law prohibitions were first limited by allowing maintenance if the alleged maintainer had a certain kind of

20. Id. at 63.65. See also 3 W. Holdsworth, A History of Englisir LAw 395.99 (3d ed. 1924); $8 \mathrm{id}$. at 397-402, and P. WINFIELD, THE History OF CONSPIRAGY AND AUUSE OF LeEAL Procedure 131-60 (1921).

21. Radin, supra note 19 , at $65-66$.

22. Id. at 57-59.

23. Winfield, Assignments of Choses in Action in Relation to Maintenance and Cham. erty, 35 L.Q. REv. 143, 143-62 (1919); Radin, supra note 19, at 67-68.

24. G. Costigan, Cases and Other Authorities on the Legal Profession and ITS Etulics 643-49 (2d ed. 1933); J. CoHen, The Law: Business or Profession? 205-10 (1916); 1 . DrINkER, LeGAL ETHICs 176 (1953); Radin, Contingent Fees in California, 28 CALIF. L. REv. 587, 589 (1940); Buckley v. Service Transportation Corp., 277 App. Div. 224, 98 N.Y.S.2d 586 (1950).

25. Other reasons for rules against stirring up litigation will be discussed infra.

26. See Annot., 139 A.L.R. 620 (1942). 
relationship with the suitor, for example, landlord-tenant, master-servant, and blood relations. ${ }^{2 \pi}$ When the suitor and the maintainer were not within the exceptions courts and legislatures began to abandon the common law policies further by looking at the maintainer's intent, not at a characterization of his act. In New York, for example, the acts of maintenance must be done "with a corrupt or malicious intent to vex and annoy."28

The offense does not consist in promoting either private suits or public prosecutions when the sole object is the attainment of public justice or private right, but in the prostitution of these remedies to mean and selfish purposes. ${ }^{20}$

The common law dies hard, though, and the feudal attitudes about litigation still appear. A Georgia court writing in 1935 could have easily written its explanation of champerty centuries ago.

The exciting or stirring up of suits may be upon grounds that are absolutely just and well founded, and yet the Penal Code properly states that if any person makes a practice of stirring up suits or exciting quarrels between individuals, he becomes guilty of a misdemeanor. ${ }^{30}$

As long as the emphasis is on the act of maintaining a suit rather than on its motive or effect, courts will strike indiscriminately at those legal services which serve along with those which merely vex. This broad prohibition is especially ironic since certain groups are prevented from protecting the oppressed in the name of a doctrine created to prevent oppression..$^{31}$

\section{Corporate Practice of Law}

One of the easiest ways a court can outlaw group legal services is by employing the doctrine that a corporation cannot practice law. Many

27. Id. at 636-40.

28. N.Y. PEN. LAw § 322, cited in People v. Budner, 13 App. Div. 253, 256, 215 N.Y.S.2d 791,794 (1961).

29. 9 C.J.S. Barratry \& 2, at 1547, cited in People v. Budner, 13 App. Div. $253,256,215$ N.Y.S.2d 791, 794 (1961). See also Commonwealth v. M'Culloch, 15 MIass. 277 (1818); Golden Commissary Corp. v. Shipley, 157 A.2d 810, 815 (Mun. Ct. App. D.C. 1960).

30. Scott v. State, 53 Ga. App. 61, 65, 185 S.E. 131, 133 (1935). The court's attempt to blame the anachronism on the legislature was a ruse since the Code made only inciting "unjust and vexatious suits" a misdemeanor. GA. CODE ANN. § 26-7410. Sce also Atchison, T. \& S.F. Ry. v. Andrews, 338 Ill. App. 552, 88 N.E.2d 364 (1949) (there vere serious questions in this case about the attorney's competence and about his overbearing the prospective client, but the court concentrated mainly on the stirring up of litigation without looking at the merits of the suit or the maintainer's motive); Ackerman v. State, 124 Tex. Crim. 125, 61 S.TW.2d 116 (1933).

31. Murphy, The South Counterattacks: The Anti-NAACP Laus, 12 W. PoL Q. 371 , 374-76 (1959); NAACP v. Button, 371 U.S. 415, 445 (1963) (concurring opinion of Douglas, J.); Reference, Inciting Litigation, 3 RACE REL. L. REP. 1257, 1263.60 (1958). 
group legal services are incorporated and clearly fall within the proscription. The process of decision usually takes the form of a simple syllogism. A corporation cannot practice law. This association (union, club) is a corporation which practices law (provides, recommends, or pays lawyers). Therefore, the association's activities are illegal. ${ }^{32}$ But courts rarely tell us why corporations cannot practice law; the reasons they give, as one commentator quaintly remarked, are no more than "hocus pocus." 33

For example:

The practice of law is not a business open to all, but a personal right, limited to a few persons of good moral character, with special qualifications ascertained and certified after a long course of study, both general and professional, and a thorough examination by a state board appointed for the purpose. The right to practice law is in the nature of a franchise from the state conferred only for merit. It cannot be assigned or inherited, but must be earned by hard study and good conduct. It is attested by a certificate of the Supreme Court, and is protected by registration. No one can practice law unless he has taken an oath of office and has become an officer of the court, subject to its discipline, liable to punishment for contempt in violating his duties as such, and to suspension or removal. It is not a lawful business except for members of the bar who have complied with all the conditions required by statute and the rules of the courts. As these conditions cannot be performed by a corporation, it follows that the practice of law is not a lawful business for a corporation to engage in. As it cannot practice law directly, it cannot indirectly by employing competent lawyers to practice for it, as that would be an evasion which the law will not tolerate..$^{34}$

Or:

The practice of the law is personal. It is open only to individuals proved to the satisfaction of the court to possess sufficient general knowledge and adequate special qualifications as to learning in the law and to be of good moral character. After one has been sanctioned in these respects, the oath as an attorney must be taken, whereby one becomes an officer of the court and subject to its discipline for violation of his obligations even to the extent of removal from his office. A dual trust is imposed on attorneys at law: they must act with all good fidelity both to the courts and to their clients. They are bound by canons of ethics which have been

32. See, e.g., Doughty v. Grills, 371 Tenn. App. 63, 94, 260 S.W.2d 379, 392 (1952).

33. Lewis, Corporate Capacity to Practice Law-A Study in Legal Hocus Pocus, 2 Mo. L. REv. 342 (1938).

34. In re Co-operative Law Co., 198 N.Y. 479, 483, 92 N.E. 15, 16 (1910). 
the growth of long experience and which are enforced by the courts. ... The relation of an attorney to his client is preëminently confidential. In addition to adequate learning, it demands on the part of the attorney undivided allegiance, a conspicuous degree of faithfulness and disinterestedness, absolute integrity, and utter renunciation of every personal advantage conflicting in any way directly or indirectly with the interests of his client. Only a human being can conform to these exacting requirements. Artificial creations such as corporations or associations cannot meet these prerequisites. ${ }^{35}$

It is true, of course, that a corporation cannot take an oath and has no human qualities. It does not follow that the lawyers employed by the corporation are equally disabled. Whatever education or ethical standards must be enforced can be enforced against the individual lawyers. Nor is it clear why the court cannot discipline the lawyers or even the laymen who own or direct the corporation if it engages in unethical conduct. These answers are becoming increasingly acceptable to some who had opposed corporate practice, especially since the tax benefits of incorporating have become manifest. ${ }^{36}$ However, in spite of the growing recognition that it makes no sense to prohibit a group of people from practicing law simply because it is incorporated, there are still attempts to outlaw group legal services for that reason. ${ }^{3 i}$

Other concerns which are related to, but do not necessarily depend upon, the corporate form of the organization are more plausible. For example, there is the fear that an organized group which provides legal services might interfere with the attorney-client relationship, ${ }^{38}$ or attempt to control the lawyer in some way harmful to the client. ${ }^{30} \mathrm{Or}$, even if the organization does not consciously do either of these things, there is the possibility that the mere existence of the organization will force the lawyer to divide his loyalties between the client and the organization. ${ }^{40}$ These fears are legitimate because we are, or should be, concerned that the lawyer perform the most effective possible service

35. In re Opinion of the Justices, 289 Mass. 607, 613, 194 N.E. $313,316-17$ (1935).

36. See In re The Florida Bar, 133 So. 2d 554 (Fla. 1961); Bje and Young, Law Firm Incorporation in Colorado, 34 RockY MiT. L. REv. 427 (1962).

37. See Brief for the ABA as Amicus Curiae at 17, Brotherhood of Railroad Trainmen v. Virginia ex rel. Va. State Bar, 377 U.S. 1 (1964); State Bar Ass'n v. Connecticut Banl \& Trust Co., 145 Conn. 222, 234-36, 140 A.2d 863, 870-71 (1958).

38. See, e.g., People ex rel. Courtney v. Ass'n of Real Estate Taxpajers, 354 1ll. 102, 109, 187 N.E. 823,826 (1933).

39. See, e.g., Richmond Ass'n of Credit Mien v. Bar Ass'n of City of Richmond, 167 Va. 327, 339, 189 S.E. 153, 159 (1937); Canon of Professional Ethics 35.

40. See, e.g., In re Co-operative Law Co., 198 N.Y. 479, 483-84, 92 N.E. 15, 16 (1910), and ABA, Information Opinion of the Committee on Unauthorized Practice of the Law, 36 A.B.A.J. 677 (1950). 
for his client. An organization which can exert pressure on the lawyer or which interferes with the direct communication between attorney and client can direct the lawyer's major concern away from his client.

There would be little quarrel with the courts or the bar associations if they punished those group legal efforts which have sacrificed their clients' interests. However, those who have opposed group legal services seem to have assumed that all control by an organization of its lawyers interferes with the attorney-client relationship, that all interferences hurt the client, that the possibility of conflict exists equally in all group services, and finally that the mere possibility of conflict has, in fact, or will, in fact, cause the individual lawyer to sacrifice his client's interest. If rules of legal ethics are justified ultimately because they protect the client's interest, then there should be a sharp focus on exactly how and when the client is hurt. The quarrel, then, is not with the policies behind prohibition of corporate practice, but with their indiscriminate application.

For example, the very general fear that an organization will interfere with the attorney-client relationship often obscures discussion of when the relationship exists and when it is really necessary. Undoubtedly, a close and constant communication between the attorney and the client helps the lawyer serve his client best in most cases. However, many group legal services maintain a strict attorney-client relationship. The lawyer recommended by the BRT is in constant contact with the injured workman, as is the NAACP lawyer with his client. The attorney and client communicate directly, not through the organization which brought them together.

There are some plans, though, in which the organization does act as an intermediary. In those cases the courts should be especially careful that the intermediary does not prevent adequate communication. But, again, increased care does not necessitate a blanket disapproval of all group intermediaries. In some situations, direct communication is less necessary than in others. The Illinois Association of Real Estate Taxpayers was organized specifically to challenge the legality of Illinois property taxes. Members authorized the Association to prosecute suits in their behalf for this purpose. ${ }^{41}$ At times they were made plaintiffs without further consultation. It is not clear why a strict attorney-client relationship was necessary here. Presumably each member's interest in the litigation coincided with the interest of the others. The Associa-

41. People ex rel. Courtney v. Ass'n of Real Estate Taxpayers, 354 Ill. 102, 187 N.E. 823 (1933). 
tion's goals were well publicized, and an individual with interests different from the Association's would not have joined.2

The same lack of concern about the client's interest is evident when the bar associations and the courts talk about group "control" over lawyers without distinguishing among kinds and degrees of control. Two courts have prohibited the Brotherhood of Railroad Trainmen, which solicits FELA cases for a limited number of approved attorneys, from fixing the rate which the lawyer can charge and from requiring the attorneys to pay for the cost of the solicitation service. ${ }^{13}$ The Brotherhood did not attempt to control the attorneys in any other way. They were free to consult with the injured trainmen and conduct the litigation or settlement free from restraint. Although the financial arrangement was determined by the organization, the strategy of litigation was determined by the attorney and client. The only kind of control exerted by the Brotherhood seemed to benefit its members since it provided cheaper, more efficient service. ${ }^{44}$ Yet the practice was outlawed, because "control" was bad.

Finally, and most importantly, arguments about "conflict of interest" illustrate the tendency to infer harm from the possibility that it might occur. The fear that the existence of an organization will divide the lawyer's loyalty between the organization and the client rests on many uncritical assumptions; for example, that the interests of the client and the interests of the organization necessarily conflict. Some organizations have no institutional interest at all which could conflict with the individual litigant's interest. ${ }^{45}$ The Brotherhood of Railroad Trainmen's stated purpose is to enforce the FELA so that the Brothers will receive ample compensation for their injuries. This purpose coincides exactly with the trainman's interest. If the BRT expanded its program and recommended estate and divorce lawyers, or if it hired its own lawyers to provide these services, there would be an even smaller possibility of conflict. There are organizations, of course, which do have very strong institutional interests, organizations with a cause-the

42. The Association was outlawed, nonetheless, and partly because there was no attorney-client relationship. 354 IIl. 102, 109, 187 N.E. 823, 826 (1933).

43. In re Brotherhood of Railroad Trainmen, 13 Ill. 2d 391, 398, 150 N.E.2d 163, 167 (1958); In re O'Neill, 5 F. Supp. 465 (E.D.N.Y. 1933).

44. There are other ways in which control by the organization may benefit the client. For example, one usual check on the quality of a lawyer's work is the client himself. Since the clients of many group legal services will not be paying, the cffectiveness of that check might be diminished. The organization itself must then take over the job of controlling the quality of the work.

45. See Note, The Unauthorized Practice of Law by Lay Organizations Providing the Services of Attorneys, 72 HARv. L. REV. 1334, 1339 (1959). 
NAACP Legal Defense Fund, the Association of Real Estate Taxpayers, etc. ${ }^{46}$ However, these organizations usually publicize their goals widely, and individuals who use their legal services often do so because their interests coincide.

Sometimes this answer will not be satisfactory. If the BRT decides that it must establish a precedent, then its interest in that precedent might conflict with the Brother's interest in recovery. Or, if the Legal Defense Fund defends a Negro convicted of rape and sentenced to death in order to assert that Negroes are denied equal protection in sentencing, the organization's interest in the equal protection claim and the defendant's interest obviously do not coincide completely. The defendant would as soon have his conviction reversed because of an illegal search and seizure, or because the elements of the crime were not proven. However, the possibility that the Legal Defense Fund's institutional interest might conflict with the client's interest does not mean that the Defense Fund lawyer allows the conflict to affect his action. ${ }^{47}$ In fact, even a casual reading of the Defense Fund's briefs in its rape cases, and in many other cases where the possibility of conflict exists, will prove that clients are not sacrificed for the sake of legal arguments. There may be organizations which do indulge and lawyers whose zeal for a principle outweighs the client's interest, but these cases should be dealt with on an individual basis.

In the cases of gross abuse it will be quite easy to tell when the lawyer subverts his client's interest. But more subtle abuse is also possible. It is this possibility which may force the courts to look for the causes of the harm rather than for the harm itself. From the existence of certain specific practices, the court would predict that the client's interest might be ignored. For example, the fact that the BRT set the price of its lawyers would indicate that it might exercise control over those lawyers to the detriment of the Brothers. If an organization prevented direct communication between lawyer and client, a court might see a potential injury to the client even if no particular interference proved harmful. If the interests of the organization and the client did not coincide completely, the court might predict that sometime in the future the lawyer would choose to act in the organization's interest rather than in the client's.

46. See NAACP v. Button, 371 U.S. 415, $462-63$ (1963) (dissenting opinion of Harlan, J.).

47. Mr. Justice Harlan, dissenting in NAACP v. Button, 371 U.S. 415, recognized that the existence of a conflict does not necessarily induce the lawyer to misconduct. "[T]he lawyer necessarily finds himself with a divided allegiance-to his employer and to his clients -which may prevent full compliance with his basic professional obligations." Id. at 460 (emphasis added). 
These predictions, though, seem to contradict assumptions which form the foundations of the legal profession. Generally, we assume that a lawyer is an advocate, serving no interest but his client's. If a lawyer in a law firm is defending an antitrust suit for a small client, we do not normally suspect that he is subverting this client's interest in order to create a precedent favorable to the firm's bigger clients. If an independent lawyer is a member of SNCC, or believes in its goals, or perhaps even is paid to do some of its tax work, we do not think that in defending a Negro in an assigned criminal case he will press SNCC's favorite legal theories rather than the ones most beneficial to his client.

So far these assumptions about the lawyer's sense of responsibility have worked reasonably well. When they don't, dissatisfied clients may provide a means for detection. There is no reason to make different assumptions about lawyers working for group legal services or to think that a group legal service which habitually sacrifices its clients' interests will not soon be found out.

\section{Advertising and Solicitation}

The proscriptions against advertising and solicitation ${ }^{48}$ were among those rules of etiquette so important to the early legal profession. ${ }^{40}$ Lawyers working closely together in a communal atmosphere would seem unduly competitive and ungentlemanly if they advertised or solicited business. The need for these social rules has diminished because the legal profession has changed so much. However, other, more modern justifications have been advanced. The claim has been that solicitation and advertising are equivalent to "ambulance chasing," ${ }^{50}$ that they stir up litigation, ${ }^{51}$ and that they commercialize the profession. ${ }^{2}$

The spectre of ambulance chasing makes rational discussion of advertising and solicitation difficult. The injured pedestrian is rushed to the hospital, followed by the eager (and, we assume, incompetent) lawyer, or his agent, pen in hand, contract in pocket, ready to make the kill. The lawyer oozes his way into the hospital room, interrupts the grieving family, and fast-talks the broken man into signing a 60 per cent contingent fee contract. A slight change alters the picture con-

48. See, e.g., Canons 27, 28, 40, 43, 46.

49. H. DRINKER, LEGAL ETHICS 210-12 (1953).

50. See, e.g., In re Cohn, 10 IIl. 2d 186, 190, 196 N.E.2d 301, 303 (1957); Doughty v. Grills, 37 Tenn. App. 63, 82, 260 S.W.2d 379, 387 (1952).

51. See, e.g., Canon 28 and In re WWeit, 11 App. Div. 76, 202 N.Y.S.2d 393 (1980).

52. ABA, Opinions of the Comartiee on Professional Etuics and Gnuevances, No. 8, at $71,75(1925)$. 
siderably. After the trainman is injured on his job, his shop steward informs the Legal Aid Bureau of the BRT. The Legal Aid representative rushes to the hospital and into the injured trainman's room. (He has barely beaten the railroad's claim adjuster to the door. ${ }^{53}$ ) The Legal Aid representative informs the injured workman that the Brotherhood has arranged for highly competent and successful lawyers to represent all injured workmen at a substantially reduced price. The Brotherhood will also help investigate the case in preparation for possible litigation. The injured workman agrees to employ the lawyer suggested by the Brotherhood and signs a contract to that effect.

The scenes may be caricatures, but the lesson remains nonetheless. Not all "ambulance chasing" is the same, and there is no good reason to lump all solicitation or advertising together under the same label. The first lawyer has abused the client, while the second has provided him with a useful service. Lawyers should be condemned only if they overbear their clients for the purpose of forcing upon them unneeded, incompetent, or overpriced legal services. ${ }^{54}$

In most group legal services cases no distinction has been made among kinds of ambulance chasing. The Illinois Supreme Court recognized that the BRT's program of solicitation protected Brothers against an aggressive railroad claims policy. ${ }^{55}$ Nonetheless, the court enjoined the Brotherhood's agents from carrying contracts to the injured workmen.56 Using the same "ambulance chasing" rationale, other courts have been even more severe, enjoining the entire soliciting arrangement. ${ }^{57} \mathrm{~A}$ few judges have not viewed all solicitations alike, but those judges have been a minority. ${ }^{68}$

The second claim, that solicitation and advertising incite litigation,

53. See In re Brotherhood of Railroad Trainmen, 13 Ill. 2d 391, 396, 150 N.E.2d 163, 166 (1958); Brotherhood of Railroad Trainmen v. Virginia ex rel. Va. State Bar, 377 U.S. 1, 3-5 (1964).

54. This approach was taken in Chreste v. Louisville Ry., $167 \mathrm{Ky} .75,81,180$ S.W. 49, 53 (1915), and is suggested in the Brief of the ABA as Amicus Curiae, at 12. Brotherhood of Railroad Trainmen v. Virginia ex rel. Va. State Bar, 377 U.S. 1 (1964).

55. In re Brotherhood of Railroad Trainmen, 13 Ill. 2d 391, 396, 150 N.E.2d 163, 166 (1958).

56. Id. at 398,150 N.E.2d at 167.

57. See, e.g., State ex rel. Beck v. Lush, 170 Neb. 376, 103 N.W.2d 136 (1960); Hulse v. Brotherhood of Railroad Trainmen, 340 S.W.2d 404 (Mo. 1960). For a longer discussion of the Brotherhood's "ambulance chasing," see Doughty v. Grills, 37 Tenn. App. 63, 82-90, 260 S.W.2d 379, 387-90 (1952).

58. See, e.g., Ryan v. Pennsylvania R.R., 268 Ill. App. 364 (1932); Hildebrand v. State Bar, 36 Cal. 2d 504, 515, 521, 225 P.2d 508, 514, 518 (1950) (dissenting opinion of Carter and Traynor, JJ.). Mr. Justice Black's statement in Brotherhood of Railroad Trainmen v. Virginia ex rel. Va. State Bar that the BRT's activity was not "ambulance chasing" may force the majority into viewing "ambulance chasing" in a more discriminating way, but the cffect of his language is not yet clear. 
is probably justified. If lawyers use these techniques, not only will they be making themselves more easily available, but indirectly they will be educating people about their legal rights. Therefore, it is likely that more suits will be brought. However, why should an increase in litigation be considered bad? There was a time when litigation could be considered an evil in itself, but these reasons no longer exist. Perhaps there is a feeling that a litigious society would simply be an unpleasant society in which to live. This vague feeling of uneasiness does not seem an adequate foundation upon which to build a rule against stirring up litigation. Perhaps there is a feeling, too, that courts are burdened enough without having more suits stirred up. However, a rule against stirring up litigation is an unsatisfactory way of deciding which claims will and which claims will not be heard. The rule does not screen out certain categories of claims or claims with dubious merit. It screens out certain kinds of people-those who are too ignorant to know when they have a legal claim and those who are too poor to be able to afford a lawsuit. Others in our society need not depend upon groups or individual lawyers who solicit business and advertise their wares.

Some judges and commentators have seen solicitation as an evil particular to certain kinds of litigation. There has been a special bias against lawyers who solicit divorce cases since there is a strong public policy against divorce in most states. ${ }^{50}$ Conversely, lawyers who solicit and stir up certain kinds of favored litigation have been exempt from ethical stigma. When an Atlanta finance corporation attacked the Atlanta Bar Association for advertising and soliciting claims against allegedly usurious finance companies, the Georgia court "commended rather than condemned" the Bar Association for its ostensibly unethical conduct. ${ }^{60}$ Even the American Bar Association recognized that the American Liberty League's solicitation of suits challenging New Deal legislation was "wholesome and beneficial" because the suits presented constitutional issues. ${ }^{61}$ If a court could articulate some reason why a particular kind of litigation should not be encouraged, then perhaps it would be legitimate to outlaw soliciting that kind of litigation. For example, a court might claim that the mere threat of divorce actions destroys marriages. There might then be a legitimate interest in not

59. See Annot, Encouraging Divorce Litigation as a Grounds for Disbarment or Sus. pension, 9 A.L.R. 1500 (1920); Comment, A Critical Analysis of Rules Against Solicitation by Lawyers, 25 U. CFI. L. REv. 674, 678 (1958).

60. Gunnels v. Atlanta Bar Ass'n, 191 Ga. 366, 381, 12 S.E.2d 602, 610 (1940).

61. ABA, Opinions of the Conmittee on Professional Etulos and Grievanices, No. 148 , at 308,311 (1935). 
having lawyers explain the divorce laws to quarreling couples. If the court felt that too many stockholders' derivative suits were hold-ups, it might then be legitimate to outlaw solicitation of these suits.

However, even in these cases the argument for preventing solicita* tion is dubious. First, there would have to be very good evidence that the evil effects of solicitation really would occur. And second, outlawing solicitation might be too drastic a solution. For example, in the case of stockholders' derivative suits, perhaps it might solve the problem of phony claims if a bond were required from the stockholders before suit.

The third major argument against solicitation and advertising, the commercialization claim, is the hardest to attack because it is the most deeply ingrained in the lawyer's feeling of dignity and self-importance. "The essential dignity of the profession forbids a lawyer to solicit business or exploit his professional services." 62 The argument goes further, of course, since even lawyers recognize that their dignity is of little concern unless its absence affects the quality of justice.

... [F] urnishing, selling or exploiting ... the legal services of members of the Bar is derogatory to the dignity and self-respect of the profession, tends to lower the standards of professional character and conduct and thus lessens the usefulness of the profession to the public.... ${ }^{3}$

The italicized portion of the preceding statement is the essential part of the commercialization claim. Unfortunately, some courts and lawyers make the claim-"The degradation of the bar is an injury to the state" 64 - on faith alone. This easy equation of the bar's interest and the public's interest must be challenged. In a generally commercialized society, why is there the assumption that the public will look askance at lawyers who employ commercial techniques? And why is it so confidently assumed that a legal profession ill-respected by some cannot perform its function adequately? The legal profession is already highly commercialized $^{65}$ and ill-respected by some, ${ }^{60}$ and yet it seems to be doing its job. ${ }^{67}$

Nonetheless, there may still be circumstances in which these ques-

62. ABA, Opinions of the Commitree on Professional Ethics and Gruevances, No. 8, at $71,75(1925)$.

63. Id. (emphasis added).

64. In re Co-operative Law Co., 198 N.Y. 479, 484, 92 N.E. 15, 16 (1910).

65. Q. JOHNSTONE \& D. HOPSON, LAWXERS AND THEIR WORK 199-271 (1967).

66. See, e.g., Blaustein, What Do Laymen Think of Lawyers? Polls Show the Need for Better Public Relations, 38 A.B.A.J. 39 (1952).

67. See Riesman's suggestion that a certain amount of public disrespect for lawyers is perfectly tolerable. Riesman, Some Observations on Law and Psychology, $19 \mathrm{U}$. Cur. L. REV. 30, 34 (1951). 
tions can be answered to support the assumptions of those who would outlaw group legal services because of their commercial techniques. Some kinds of gaudy and inflated advertising which would lower the dignity of the bar might also mislead the public. Perhaps these should be prohibited. But in the context of outlawing group legal services the whole argument about commercialization seems quite false. If the reputation of the bar is really important, then lawyers should at least recognize the possibility that outlawing group legal services would hurt their reputation more than upholding the non-commercial image would help it, especially since it is possible for the public to view the fight against group legal services as nothing more than an organized monopoly's attempt to maintain its financial position. This view would not be completely unwarranted. The entire war against the typical unauthorized practitioner (title insurance companies, trust companies, accountants, etc.), waged in terms of "commercialization," has many of the elements of economic groups fighting over markets, ${ }^{08}$ complete with market treaties ${ }^{69}$ and market compromises. ${ }^{70}$

Suspicion of the bar's motives becomes even stronger when the groups which are being outlawed apparently satisfy "an unfulfilled public need for legal services," ${ }^{11}$ and at a cheaper price. Thirty years ago Weihofen asked,

Why is it that individuals may band together to provide themselves with cheaper insurance, cheaper groceries, higher wages, better prices, easier credit, lower taxes, better health,--everything, except better or cheaper legal advice and aid?i2

It is hard to imagine a plausible answer unless it is in terms of preserving the bar's economic monopoly, an answer repugnant to the very principle for which the bar is supposedly fighting - the maintenance of a profession, not a business. ${ }^{73}$

68. See Johnstone, The Unauthorized Practice Controversy, A Struggle Among Pou'er Groups, 4 KAN. I. REv. 1 (1955).

69. 3 Miartindale-Hubbel LAW DiRectory 197A-211A (1957).

70. See, e.g., Hulse v. Criger, 363 Mo. 26, 247 S.W.2d 855 (1952); State Bar Ass'n of Conn. v. Connecticut Bank \& Trust Co., 145 Conn. 292, 140 A.2d 863 (1958). The best article on the bar's trouble in this regard remains Llewellyn, The Bar's Troubles and Poulticesand Cures?, 5 LAW AND CONTENM. Prob. 104 (1938).

71. Progress Report of the Committee on Group Legal Services, 39 Cal. S.B.J. 639, 652.59 (1964). See also WALD, LAw AND POVERTY (prepared as a yorking paper for the National Conference on Law and Poverty, 1965); In re Community Legal Services, Inc., Pa. C.P. 29-33, March Term, 1966, No. 4968 (35 U.S.L.W. 2017, June 30, 1960) and materials cited therein.

72. Weihofen, "Practice of Law" by Non-Pecuniary Corporalions: A Social Utility, 2 U. CHI. L. REv. 119, 128 (1934).

73. See also H. DrinkER, LeGAL ETHICs 167 (1953); Drinker, The Ethical Lauyer, 7 U. FLA. L. REV. 375, 382 (1954). 
None of the arguments advanced here depends upon whether the group legal service is profit-making or non-profit-making. Either kind of organization may provide beneficial services, and either kind may abuse the client. In both cases the test of the organization's acceptability should be the benefit to the public in terms of price, effectiveness, and competence of the legal service. For example, even if the BRT were a profit-making organization because it received payments from its recommended lawyers, ${ }^{74}$ the service it provided was still cheaper and more effective than the individual member could have obtained for himself. Otherwise, at least without a showing of coercion, we may assume the Brother would have gone elsewhere with his business.

\section{Some Suggestions and Some Problems}

Although the rules of legal ethics are too broad and indiscriminate, they do embody several important and viable policies. A reformulation is necessary, though, in order to insure that the new rules do not go beyond the policies they are designed to implement. Writing new rules will be difficult, but the previous discussion indicates some general directions.

(1) The state should be allowed to make sure that its judicial machinery is not being used simply for harassment. The rules should be framed to preclude the possibility that the mere tendency to harass will be outlawed. Actual harassment, as well as intent to harass, should be required. If the party accused of harassing wins his claim, the accusation should fail. So, too, should it fail if the party has what seems to be a viable claim, even if he ultimately loses or settles it.

(2) Lawyers should be punished for sacrificing clients' interests to the interests of an organization. Here again, the mere possibility of conflict should not be enough. Regardless of the institutional set-up (control over fees, rebates, interferences with the direct attorney-client relationship) or the profit-making nature of the organization, it should be allowed to operate until some of the evil which is feared occurs. A specific and particular showing of harm to clients should be shown.

(3) Lawyers should be prevented from taking advantage of injured men in order to charge too much or force unneeded or unwanted legal services upon them. Objective criteria for prices are necessary to apply this rule. A simple method of insuring that lawyers do not take advantage of the injured man would be to keep all lawyers (or their agents) out of hospitals or to require that someone in the family, or a

74. Cf. In re Brotherhood of Railroad Trainmen, 13 Ill. 2d 391, 150 N.E2d 169 (1958). 
friend, or the doctor give permission before a lawyer could see the patient. Once the patient is well enough to consider the lawyer's proposal rationally, he can fend for himself. A court can implement these rules by refusing to enforce the contracts until they are scrutinized very closely.

(4) A lawyer who chases ambulances may be incompetent, and if so, something should be done about him. However, we cannot simply assume his incompetence. Further, the problem of qualification and ability is not limited to lawyers who practice for groups or lawyers who solicit and advertise. Whatever is to be done about incompetent ambulance chasers must also be done to incompetent lawyers generally.

(5) If some forms of advertising are misleading or distasteful, these can be prohibited without outlawing all attempts to make the availability of lawyers more widely known.

(6) Stirring up particular kinds of litigation may be prohibited, but only if there are honest and well-grounded reasons to believe that there is something in the nature of the particular litigation which gives society an interest in preventing it. The interest must be a very special kind, strong enough to prohibit solicitation but not strong enough to eliminate the cause of action entirely. Divorce litigation or litigation between members of a family might be examples. A general feeling that too much litigation on any subject is unpleasant will not do. Also, once the particular evil is isolated, the remedy should be tailored to it. Solicitation should be banned only if more narrow solutions fail.

These suggestions raise questions. How should harassment be defined? Can a rule based on the intent to harass be enforced? Is it possible to tell when a lawyer is sacrificing his client's interest for the sake of the organization? Who is to determine when a lawyer is taking advantage of his client? For example, when is the price of legal services "too much"? And how is competent performance to be tested? The seriousness and difficulty of these questions should not be minimized. Indeed, it may be that we will be unable to answer them and that we will be forced to return to broader and more indiscriminate rules. However, the rewards of success seem great enough at least for us to make an effort.

\section{Group Legal Services and the Constitution}

Pleas for reform have been heard before. The possibility that they will be heeded, though, seems much greater now. In part this is because 
the pressure for reform has increased. But additionally, the reformers have found a powerful, if not wholly conscious, ally in the Supreme Court. During the last four years the Court has begun to explore the rules of legal ethics. In two important cases the Court found certain activities of group legal services protected by the First and Fourteenth Amendments, and held that particular rules of legal ethics could not be used to outlaw these practices. ${ }^{75}$ Now the Court has agreed to review a third case. ${ }^{76}$ Together, the three cases may provide a strong impetus for reform.

NAACP v. Button ${ }^{77}$ was a suit by the Association to enjoin Virginia from applying five recently passed statutes regulating the practice of law. ${ }^{78}$ By the time the case reached the Supreme Court, the Virginia courts had declared four of the five acts unconstitutional. ${ }^{70}$ The statute before the Supreme Court, Chapter 33, amended the previous Virginia laws against solicitation and maintenance by increasing the categories of people who could be found guilty of the crimes. The statute provided punishment not only for the solicitors and maintainers, but also for any of their agents or any lawyer who took employment from such people. Clearly the Association's activities were prohibited by the statute. The Association's entire legal program was based on soliciting suits through speeches, circulars, personal contacts, etc., and then maintaining the suits by paying Association lawyers to handle them. It is probable, though, that the Association's activities were prohibited under the rules of the Virginia Supreme Court, which are similar to the American Bar Association's Canons of Professional Ethics. ${ }^{80}$ The Association solicited business for specified lawyers; it maintained suits; it advertised; it controlled the lawyers' fees; it was a lay intermediary; it incited litigation; and it was a corporation practicing law. In fact, the Virginia Supreme Court used Canons 35 and 47 as alternate grounds for outlawing the NAACP's activities, and used as reasons for uphold-

75. Brotherhood of Railroad Trainmen v. Virginia ex rel. Va. State Bar, 377 U.S. 1 (1964); NAACP v. Button, 371 U.S. 415 (1963).

76. United Mine Workers of America v. Illinois State Bar Ass'n, 386 U.S. 941 (1967)

77. 371 U.S. 415 (1963).

78. Chs. 31, 32, 33, 35, 36 [1956] Va. Acts, Ex. Sess. Originally, the Legal Defense Fund joined the Association, but when the case finally reached the Supreme Court only the Association was involved. The Fund's suit remained in the Federal District Court for the Eastern District of Virginia.

79. See NAACP v. Harrison, 202 Va. 142, 116 S.E.2d 55 (1960). The first decision in the proceedings, NAACP v. Patty, 159 F. Supp. 503 (E.D. Va. 1958), declared chapters 31, 82, and 35 unconstitutional, but the Supreme Court reversed on the procedural ground that the Virginia courts had not had an opportunity to construe the statute. Harrison $v$. NAACP, 360 U.S. 167 (1959). Then the case began in the Virginia courts.

80. See Rule 35, Rules for Integration of the Virginia State Bar, 171 Va. xvii, xxxii* xxxiii (1938). 
ing Chapter 33 many of the policies discussed earlier. ${ }^{81}$ Thus, although the Supreme Court had before it only the Virginia statute as amended, the Court made it clear that what it said and what it did in Button would affect the application of all the rules of legal ethics to group legal services. ${ }^{82}$

Deciding what the Court said and what it did in Button, though, is not easy. Some activity of the Association was protected by the First Amendment, and this activity was not given enough breathing space by the Virginia statute. "[S]tandards of permissible statutory vagueness are strict in the area of free expression."83 But the Court was ambiguous about exactly which activity was the "constitutionally protected activity."84 There are two candidates. The Court might have meant that the Association's program of advising Negroes to begin litigntion was a protected activity. Then Virginia's regulation against soliciting for Association lawyers would be unconstitutional because it was vague enough to discourage that general advice. Or, the Court might have meant that litigation itself was a protected activity-that any person has the "right" to become a plaintiff in a lawsuit and that the state could not bar an organization from helping him get into court, or at least not in the way Virginia attempted to do so.

The first interpretation is supported by some language in the opinion. The Court read the Virginia Supreme Court's interpretation of Chapter 33 as prohibiting a person from

[advising] another that his legal rights have been infringed and [referring] him to a particular attorney or group of attorneys (for example, to the Virginia Conference's legal staff) for assistance. . . . 85

The Court then indicated that the core First Amendment right abridged by the Virginia statute was the right to advise Negroes to litigate, not necessarily the right to refer Negroes to particular attorneys.

There thus inheres in the statute the gravest danger of smothering all discussion looking to the eventual institution of litigation on behalf of the rights of members of an unpopular minority.$^{80}$

81. NAACP v. Harrison, 202 Va. 142, 156-59, 116 S.E.2d 55, 66.68 (1960).

82. 371 U.S. at 429 n.I1.

83. 371 U.S. at 432 .

84. Id.

85. 371 U.S. at 434 .

86. Id. 
However, the Association's right to refer Negroes to particular attorneys was upheld also, but only because denying that right would endanger the core First Amendment right.

Lawyers on the legal staff or even mere NAACP members or sympathizers would understandably hesitate, at an NAACP meeting or on any other occasion, to do what the [Virginia] decree purports to allow, namely, acquaint "persons with what they believe to be their rights and ... [advise] them to assert their rights by commencing or further prosecuting a suit. . . " For if the lawyers, members or sympathizers also appeared in or had any connection with any litigation supported with NAACP funds contributed under the provision of the decree by which the NAACP is not prohibited "from contributing money to persons to assist them in commencing or further prosecuting such suits," they plainly would risk (if lawyers) disbarment proceedings and, lawyers and non-lawyers alike, criminal prosecution for the offense of "solicitation," to which the Virginia court gave so broad and uncertain a meaning. ${ }^{87}$

Although the first interpretation of Button can be supported by this language, it is an unsatisfactory interpretation, nevertheless. The Association's right to advise litigation was guaranteed by the Virginia court itself. ${ }^{88}$ If that were the only right involved, the Supreme Court would not have had to go further, unless, of course, the Virginia statute was vague enough to restrict the enjoyment of that right. The Supreme Court did say that the statute was vague and that therefore it might deter people from advising others to litigate. But the Court's reasoning on this point is at least questionable.

The Court read the statute (and its gloss by the Virginia Supreme Court of Appeals) as punishing anyone who refers another "to a particular attorney or group of attorneys." 80 This reading makes the statute quite broad, perhaps even broader than the Virginia courts intended, but broad coverage by itself does not make the statute vague. Indeed, even under the Court's reading it seems reasonably clear what the statute would permit and what it would prohibit. A person could advise others of their rights and advocate litigation as the means of vindicating them, as long as he did not suggest a particular lawyer or group of lawyers to handle the litigation. It is difficult to see how this latter prohibition could smother the general discussion of rights and litigation.

87. Id. at $434-35$.

88. NAACP v. Harrison, 202 Va. 142, 164, 116 S.E.2d 55, 72 (1960).

89. 37 I U.S. at 434 .

90. See Mr. Justice Harlan's dissent, 371 U.S. at 465-69. 
The Court argued that lawyers, members, or sympathizers who spoke at an NAACP meeting and who later "appeared in or had any connection with any litigation supported with NAACP funds . . . plainly would risk (if lawyers) disbarment proceedings and, lawyers and nonlawyers alike, criminal prosecution for the offense of 'solicitation,' to which the Virginia court gave so broad and uncertain a meaning." 01 But if the lawyer, member, or sympathizer who spoke at the NAACP meeting did not recommend "a particular attorney or group of attorneys," he would not come within the terms of the statute even as interpreted by the Supreme Court. Of course, even the most pristine clarity does not guarantee that the state officials would not misuse the statute in order to harass NAACP lawyers or sympathizers. That possibility raises very serious problems, but they are not problems of vagueness.92 If it is true that there must be "an actual vagueness component"93 in a vagueness decision, then Mr. Justice Harlan was correct when he said that the vagueness concept "has no proper place in this case and only serves to obscure rather than illuminate the true questions presented."94

There is a second reason why Button should not be read as establishing the right to advise others about litigation as the core First Amendment right. This reading, based on the vagueness doctrine, protects only part of the NAACP's litigation program-"advising Negroes of their constitutional rights, urging them to institute litigation of a particular kind," and, after the First Amendment right spreads its protective umbrella, "recommending particular lawryers. . . ." The vagueness doctrine, though, has no necessary relevance to other parts of the NAACP litigation program which the Court purported to protectmost importantly, the Association's practice of maintaining suits by paying its own staff of lawyers to handle them. The Court evidently thought it was protecting the whole program, including the financial arrangement, for it repeated several times that it was upholding the Association's activities. ${ }^{96} \mathrm{Mr}$. Justice White, who concurred in the Court's result, made explicit his understanding of what the Court held to be constitutionally protected: "advising Negroes of their constitutional rights, urging them to institute litigation of a particular kind,

91. 371 U.S. at $434-35$.

92. Compare Dombrowski v. Pfister, 380 U.S. 479, 490, with id. at 490.91 (1965).

93. Comment, The Void-for-Vagueness Doctrine in the Supreme Court, 109 U. PA. L. REv. 67, 88 (1960).

94. 371 U.S. at 465 .

95. 371 U.S. at 447 (opinion of Thite, J., concurring in part and dissenting in part).

96. E.g., 371 U.S. at 428, 444, and 371 U.S. at 442 ("the entire arrangement"). 
recommending particular lawyers and financing such litigation."07 And, as the Court was to say later in the Brotherhood case, a British union's program of retaining and paying counsel to represent members in personal injury cases was "a practice similar to that we upheld in NAACP v. Button. ..." 98 The first reading of Button is simply inadequate to this task.

Finally, most of the reasons which the Court gave for its decision were reasons which justify holding litigation to be a protected activity. The Court took a functional approach-matching the "purposes" of litigation against the "purposes" of the First Amendment, and upon finding a correspondence, held the one to come within the scope of the other. The Court seemed to focus upon two or perhaps three purposes of free speech. First, in theory, only through a system of free communication can a society arrive at the truth about any public issue. Second, free speech is essential in a democratic society in order to encourage members of the community to participate in the political process. Third, free speech performs a legitimating function. People who have been allowed to participate freely in a discussion will be more willing to accept the ultimate decision. ${ }^{00}$

Protection of litigation fits within all of these First Amendment purposes. For the society, litigation is one of the ways in which ideas about public issues are expressed.

... [T] The litigation it [the NAACP] assists, while serving to vindicate the legal rights of members of the American Negro community, at the same time and perhaps more importantly, makes possible the distinctive contribution of a minority group to the ideas and beliefs of our society. ${ }^{100}$

Litigation was not always considered a benefit to society in this way. In the common law's infancy, suits were looked upon essentially as fights between private parties to be avoided whenever possible. The only public interest was the interest in preventing physical violence in the form of self-help. This attitude has changed, and partly because the legal realists have made the now obvious point that every suit between private parties affects the public in some way. This changing attitude has manifested itself in some important changes in our legal system, especially during the 1930's. For example, the Attorney General was

97. 371 U.S. at 447 (emphasis added).

98. 377 U.S. at 7.

99. See Emerson, Toward a General Theory of the First Amendment, 72 YALE L.J. 877, $881-893(1963)$.

100. 371 U.S. at 431 . 
given the power to intervene in certain private suits to protect the public interest. ${ }^{101}$ And more important, administrative agencies were created to represent the public in what previously had been thought of as purely private, adversary proceedings. These changes represent a firm commitment to the idea that litigation has public as well as private importance.

This theory about litigation is most obviously correct in a case like Button where the suits involved controversial national issues. However, as some of the realists pointed out, private suits affect the public in all cases, not just the big ones. In deciding a tort case, a court sets its course in future torts cases. Every future tort claimant is affected, as is every insurance company, and therefore every policyholder. As the circle gets larger the effect diminishes, but the cumulative effect of the torts cases on the public is great.

Litigation, then, may be a way for people to express positions on issues of public importance regardless of the kind of suit involved. The particular motivation of the party would seem to be equally irrelevant. We do not know why NAAGP members wanted to sue for desegregated schools. Perhaps some did so simply as a matter of principle, and perhaps others did so in order that their children would have the pecuniary advantages of a better education. There is little doubt, though, that the injured Brothers sued for money alone. And, in the Brotherhood case, the Court protected these suits (and plaintiffs) as well as suits (and plaintiffs) motivated by political or moral principle, and with good reason. Through their lawsuits these plaintiffs were taking a position on issues which would affect the public. That fact is not altered because some of the plaintiffs wanted to win money.

The second purpose of free speech also is furthered by declaring litigation a protected First Amendment activity. Litigation is certainly an effective (and sometimes the only effective) way for an individual to participate in the political process. This statement was true for the Negro litigants in Button. Their weak economic position insulated much of the community from their claims. Their relatively weak voting position insulated their federal and state representatives. Only the courts remained open. Before the courts, the Negroes acted like an economically or politically strong person would have acted before other governmental agencies more sensitive to his claims. ${ }^{102}$ For the Negroes, litigation was like lobbying.

101. 28 U.S.C. § 2403 (1964).

102. Cf. Comment, 58 Yale L.J. 574 (1949). 
[I]t is a means for achieving the lawful objectives of equality of treatment by all government, federal, state, and local, for the members of the Negro community in this country. It is thus a form of political expression. Groups which find themselves unable to achieve their objectives through the ballot frequently turn to the courts. Just as it was true of the opponents of New Deal legislation during the 1930's, for example, no less is it true of the Negro minority today. And under the conditions of modern government, litigation may well be the sole practical avenue open to a minority to petition for redress of grievances. ${ }^{103}$

Although the Court talked about the particular problems of participation faced by Negroes, its argument here does not depend upon the kind of litigation (or the kind of litigant) which may be involved. Litigation need not be the only avenue open to an individual. It is enough that it is one of the possible avenues. In the Brotherhood case the union members were neither politically nor economically weak. Congress was open to them, as was proven by their successful efforts to have the FELA and the Safety Appliances Act passed. But the courts, too, were important, and the Court kept that avenue open also. ${ }^{104}$

Finally, litigation performs the same legitimating function as speech, and in a similar way. When a person feels that he can speak out on an issue which concerns him, he is more likely to accept the decisions his community makes. The mere possibility that he can be heard makes any decision more legitimate. So, too, with courts and litigation. Professor Black tells the story of the constitutional crisis in 1936, of how millions of people opposed the New Deal partly because it was "usurpative and illegitimate as a matter of constitutional law,"105 and of how the Supreme Court met the crisis and quieted the people by upholding the New Deal, by legitimating it. It is not that these people liked the New Deal any better, or thought it any wiser, but at least it was legal.100

On a much smaller scale, courts perform this legitimating function all the time, the Supreme Court and constitutional issues completely aside. Whenever a court decides a case, one party's action will be "Iegitimated," and the other, presumably, will accept the action as legal, if not wise. On this foundation a society of law is built. Without a neutral and trusted arbiter there would be chaos. This is why people must have free access to courts, and must be made to feel that they have

103. 371 U.S. at $429-30$.

104. 377 U.S. at 2-4.

105. C. Black, The People and the Court 62 (1960).

106. Id. at 56-65. 
access. If some people cannot test the legal claims of others, and if these people cannot bring the state to their aid when they are in the right, there is no reason why they should trust legal decisions, either in specific cases or in general, and there is no reason why they should view the authority of any system of law in which they cannot participate as "Iegitimate." At least in cumulative effect, then, this legitimating function is as important in small private suits as it is in constitutional litigation. Indeed, if we heed the daily newspapers, it is the failure to obtain a fair hearing on the most mundane kinds of claims (landlordtenant, welfare, consumer credit) which seems to call the system's legitimacy most seriously into question.

As an analytical tool, this functional method has its limitations since many activities which are not, and could not be, protected have some of the same purposes or functions as speech. However, the method works reasonably well when it is applied to such a traditional way of expressing oneself ${ }^{107}$ - through a lawyer and in court. In any event, regardless of what justification is chosen, there is nothing particularly radical about saying that litigation is a protected activity, that people have the right to litigate. What follows, though, is radical, at least as it affects the rules of legal ethics. For if people have the right to litigate, then they may join together to help themselves or others exercise that right, and the state cannot stop them by using the broad prophylactic rules of legal ethics. If it is unclear that Button said these things, Brotherhood dispels the doubts.

A State could not, by invoking the power to regulate the professional conduct of attorneys, infringe in any way the right of individuals and the public to be fairly represented in lawsuits authorized by Congress to effectuate a basic public interest .... The State can no more keep these workers from using their cooperative plan to advise one another than it could use more direct means to bar them from resorting to the courts to vindicate their legal rights. The right to petition the courts cannot be so handicapped. ${ }^{108}$

The effect of all this is summed up by Button's pithy sentence, "[A] State cannot foreclose the exercise of constitutional rights by mere labels." 109

107. Compare Adderley v. Florida, 385 U.S. 39 (1966), with Edwards v. South Carolina, 372 U.S. 229 (1963).

108. 377 U.S. at 7.

109. 371 U.S. at 429 . 


\section{Conclusion}

We have come full circle, back to the labels of legal ethics. At least according to one court, these labels have lost their potency. Button and Brotherhood do not mean, of course, that all rules of legal ethics are invalid or that they may never be applied to group legal services. The core right to litigate may be absolute, but the right to associate for this purpose or to help others litigate need not be. Indeed, the state may have a legitimate interest in making sure that these groups do not harm the people whose rights are being implemented. The Court seemed to say as much when it declared that Virginia had not demonstrated any "substantial regulatory interest, in the form of substantive evils" which could justify prohibition of the NAACP legal program. ${ }^{110} \mathrm{~A}$ different result might be required if "substantive evils" are shown. But these evils must be real and particular, and the rules must be closely tailored to the evil. "[Where] fundamental personal liberties are involved, they may not be abridged by the states simply on a showing that a regulatory statute has some rational relationship to the effectuation of a proper state purpose ... . The law must be shown 'necessary and not merely rationally related' to the accomplishment of a permissible state policy." "111

The old justifications for the rules of legal ethics will no longer suffice. The fact is that the Supreme Court has already shown its suspicion of the "broad prophylactic rules" 112 and has begun to require new justifications for outlawing barratry, maintenance, and champerty, for prohibiting people from stirring up litigation, for preventing lay intermediaries, for the rules against solicitation. ${ }^{113}$ In essence, the Court is asking that the rules focus on the actual harm to the client or to the public. The reform in legal ethics, which had been only a matter of sound policy and good sense, may now be a matter of constitutional imperative.

March 14, 1967

110. NAACP v. Button, 371 U.S. at 444.

111. Griswold v. Connecticut, 381 U.S. 479, 497 (1965) (concurring opinion of Goldberg, J.).

112. NAACP v. Button, 371 U.S. at 438. The recent advisory opinion of the Florida Bar Association's Committee on Professional Ethics, supra note 16, also shows some suspicion of prophylactic rules, although the suspicion was not based on the Constitution. The Com* mittee was aware that abuses might develop in the OEO's proposed program, but the Committee was not willing to disapprove of the program before the abuses materialized.

113. 371 U.S. at $439-444$. 


\section{The Yale Law Journal}

Volume 76, Number 5, April 1967

\author{
Editor-in-Chief \\ Note \& Comment \\ Editors \\ Projects Editor \\ Article \& Book \\ Review Editors \\ Topics Editor \\ Managing Editor \\ Bruce A. Ackerman \\ LEONARD H. BECKER \\ JANES T. BETrS \\ STEPHEN V. BOMSE \\ RUSSELl CARPENTER \\ AlIAN Ghapin \\ Ruchard CotTon \\ BarRy G. CRaig \\ John Daum \\ Marvin J. Diamond \\ ARDEN DOSS, JR. \\ GrofFrey DRURY \\ VIRGINIA B. EISENSTEIN \\ RICHARD A. EPSTEIN \\ John Mines Evans \\ W. JoHN GLANCY \\ RICHARD GOODYEAR \\ Thomas Grey \\ Julian Dean Heller \\ David W. Hess
}

Business Secretaries

\author{
LEONARD M. Ross
}

H. JefF Greenfield

SIMYON LAZARUS III

JOSEPH N. ONEK

SILAS WASSERSTROAY

mitcezael S. Wald

Leonard Chazen

Phintr Gordon Schrag

Charles H. Herz

Thomras Haamiton Chirders, Jr.

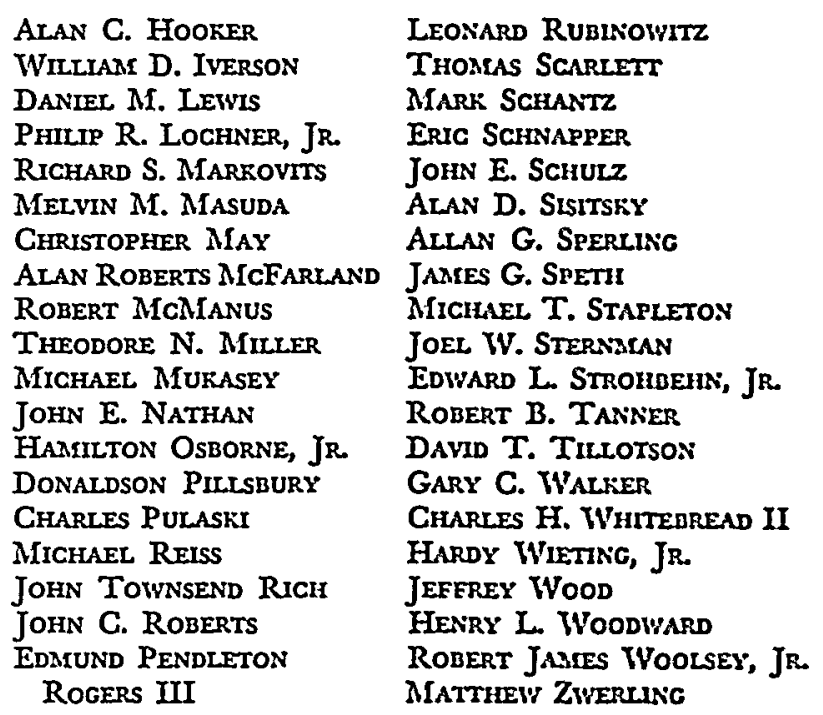

M. Olive Butterfield, Ethet Moriarty

\section{Student Contributors to This Issue}

William D. Iverson, Judicial Control of Secret Agents John Patrick Anderson, Reciprocal Dealing 